\title{
A Cross Over Trial Evaluating Combined Effect of Ruksha Virechana,Lashuna Erandadi Kashaya and Patolamooladi Kashaya in Diagnosed Patients of Non-Alcoholic Steatohepatitis
}

\author{
Shirvadkar Divyashree $\mathrm{M}^{1}$, Dr. Prashanth A $\mathrm{S}^{2}$ \\ ${ }^{1}$ Final Year MD Scholar, ${ }^{2}$ Principal, Head and Professor \\ Department of Kayachikitsa, \\ Ayurveda Mahavidyalaya and hospital Hubli, Karnataka,India
}

\begin{abstract}
The change in living habits due to increasing popularity of fast foods, sedentary lifestyle have given rise to lifestyle disorders and Non Alcoholic Steatohepatitis is one among them. Non Alcoholic Steatohepatitis (NASH) is a spectrum of Non Alcoholic Fatty Liver Disease (NAFLD) characterized by the presence of hepatic steatosis and inflammation with hepatocyte injury (ballooning) with or without fibrosis.There is no direct reference to NASH in Ayurvedic literature but based on the etiopathogenesis, signs and symptoms it can be correlated to Yakritodara.NASH has no FDA approved therapeutics, so, it is need of the hour to search an effective hepatoprotective remedy from Ayurvedic treasure of therapeutics. Hence, the present study was designed as cross over single blind clinical study with the objectives of evaluating the combined efficacy of Amapachana,Ruksha virechana and Shamanoushadhi with Lashuna Erandadi Kashaya and Patolamooladi Kashaya in the management of NASH. Overall study showed marked improvement in $60 \%$ of cases and Moderate improvement in $\mathbf{2 6 . 6 6 \%}$. Hence,it can be concluded that the combined effect of therapy with Amapachana,Ruksha virechana and Shamanoushadhis (Lashuna Erandadi Kashaya and Patolamooladi Kashaya) has shown a significant role in relieving the signs and symptoms of subjects diagnosed with Non Alcoholic Steatohepatitis.
\end{abstract}

Keywords:- Lifestyle disorders, NASH, Yakritodara, Virechana,Lashuna Erandadi Kashaya, Patolamooladi Kashaya.

\section{INTRODUCTION}

Ayurveda is an eternal science of healthy living treasures which deals with physical, psychological and spiritual well-being of the human being and covers all the aspects of human life.The secret of good health is optimum metabolism.Due to the advanced technology,busy schedule and sedentary lifestyle, there is increased popularity of fast foods leading to the impairment of metabolism in an individual making him prone to a series of disorders called as "lifestyle disorders".
Liver is an organ of the human body that performs an array of functions that help support metabolism of carbohydrates, proteins, fats; immunity, digestion, detoxification, vitamin storage among other functions. It is intertwined with nearly every system in the body; hence, it is prone to a variety of pathologies.

The term "Non Alcoholic Steatohepatitis" (NASH) was first coined by Dr. Ludwig et all in 1980 to describe a unique entity characterized by fatty changes with lobular hepatitis. ${ }^{[1] " N o n-A l c o h o l i c ~ S t e a t o h e p a t i t i s " ~(N A S H) ~}$ represents a part of a wide spectrum of Non-Alcoholic Fatty Liver Disease (NAFLD), which ranges from simple steatosis and steato-hepatitis to advanced Fibrosis and Cirrhosis. ${ }^{[2]}$ The occurrence of Fatty Liver in Type 2 Diabetics, Obese and Hypertriglyceledemics is exceedingly high.Also,the risk of severe Liver Disease goes up with increasing features of "Metabolic Syndrome". ${ }^{3]}$ Epidemiological studies suggest the prevalence of NAFLD is around $9 \%$ to $32 \%$ of general population in India with a higher prevalence in those with Obesity and Diabetes. ${ }^{[4]}$

There is no direct reference available in Ayurvedic classics correlating to Non Alcoholic Steatohepatitis.NASH can be considered as a Santarpanajanya Vyadhi and can be correlated to Yakritodara.

Liver is compared with Yakrit in Ayurvedic classics.Yakrit is derived from the Matruja Bhava ${ }^{[5]}$ and is the Mulasthana of Raktavaha Srotas ${ }^{[6]}$ which transforms Rasa Dhatu to Rakta Dhatu and plays an important role in Dhatu Parinama .Acharya Bhavamishra was the first to introduce the term "Yakritvikara" with its classification in his treatise Bhavaprakasha. ${ }^{[7]}$

In Charaka Samhita, a reference is available regarding Yakritodara in Ashtodariya Adhyaya and Udara Chikitsa Adhyaya enumerating 8 types of Udara Roga and the nidana ,samprapti ,lakshana and chikitsa of Yakritodara are similar to that of Pleehodara. As per the Ayurvedic concept, the consumption of Pitta-Kaphavardhaka-Vidahi and Abhishyandi Ahara and Vihara are responsible for the Dushti of Annavaha, Udakavaha, Rasavaha, Raktavaha, Medovaha and Pureeshavaha Srotas. Ajirna,Sthoulya and 
Prameha acts as Nidanarthakara Rogas which may result in the manifestation of Yakritodara.

Initial pathology lies at Agnivikruti which leads to the formation of Apakva Anna Rasa which in turn leads to Kapha Dosha Dushti and unequal formation and deposition of Meda in Yakrit. This condition is called as Fatty Liver.Vitiated Kapha and Meda results in Sroto avrodha which provokes Vata.Vitiated Vata again results in Agnivikruti and this cycle repeats. When Pitta gets involved in the pathogenesis, hepatocytes have inflammatory changes and the disease progresses to the next stage i.e. NASH.When Vata gets involved, Fibrosis occurs and the condition may progress to its drastic end stages Cirrhosis, Ascites, Hepato cellular Carcinoma and also pave way to other metabolic complications. Major factors responsible for the etiopathogenesis of NASH include vitiation of Samanavayu, Apanavayu, Pachakapitta, Ranjakapitta, Kledaka Kapha,Rasa,Rakta,Medo Dhatu and Pureesha.It will manifest symptoms like Dourbalya, Arochaka, Avipaka,Mala-Mutragraha, Angamarda,Chardi etc.

The pathogenesis of NASH is explained by-'Two Hit Hypothesis'.The 'first hit' results in steatosis (fatty liver) which is only complicated by inflammation. If a 'second hit' occurs,Leptin, which is an appetite reducer and a fibrogenicin vitro, is probably then needed to cause hepatic fibrosis. The components of first hit includes the release of free fatty acids from central adipose tissue, along with adipokines, drain into the portal vein as well as causing insulin resistance. These processes result in reduced hepatic fatty acid oxidation and increased fatty acid synthesis. ${ }^{[8]}$

Virechana is the most suitable Shodhana Karma for Pittaja and Raktaja Vikara and Yakrit being the Moolasthana of Raktavaha Srotas,Virechana is the Sreshta Chikitsa.It is indicated in Bahudoshavastha and Sroto avrodha. Agnideepana,Rookshana and Virechana should be administered.

NASH has no FDA (Food \& Drug Administrative agency) approved therapeutics. ${ }^{[9]}$ In spite of the tremendous advances made in modern medicine,still there is need of effective and safe hepatoprotective medicines.Hence,in this study,an effort was made to assess the efficacy of Amapachana with Ajamodadi Churna ${ }^{[10]}$ and Ruksha Virechana with Dashamoola Panchakoladi Kashaya ${ }^{[11]}$ in both the Groups, followed by Shamanoushadhi -Lashuna Erandadi Kashaya ${ }^{[12]}$ in Group A and Patolamooladi Kashaya $^{[13]}$ in Group B.

\section{* Objectives}

$>$ Aim of the Study:

To formulate effective easily available formulations in the management of Non alcoholic Steatohepatitis (NASH) aiming at good health maintenance and prevention of complications.
$>$ Objectives of the Study:

- To assess the efficacy of Ruksha Virechana in the subjects of NASH.

- To evaluate and compare the efficacy of Lashuna Erandadi Kashaya and Patolamooladi Kashaya in NASH.

- To formulate effective easily available formulations in the management of Non-alcoholic Steatohepatitis (NASH) aiming at good health maintainance and prevention of complications.

- To study the concept of Non-alcoholic Steatohepatitis in Ayurveda.

\section{MATERIALS AND METHODS}

Study Design: Cross over single blind clinical study.

Study Population : A minimum of 20 subjects diagnosed with NASH fulfilling the diagnostic and inclusion criteria were selected for the study.

$>$ Plan of work

The entire study was designed to be conducted in three phases.

- PHASE I

$\checkmark$ Detailed literature review, done extensively using tertiary resources, secondary resources, primary resources.

$\checkmark$ Procure the necessary documentation: Designing of data entry form, informed consent document, patient information sheet.

$\checkmark$ Ethical committee approval: Ethical clearance was obtained from the Institutional Ethics Committee of Ayurveda Mahavidyalaya Hubli.

\section{- PHASE II}

$\checkmark$ The sample size was collected which comes under the inclusion and exclusion criteria at the time of enrolment.

$\checkmark$ Data was collected using data entry form after explaining patient information sheet and signing informed consent document.

- PHASE III

$\checkmark$ Reports were analyzed using various statistical tools.

$\checkmark$ Reporting of results and presentation.

\section{Sources of data:}

Patient interview and patients case records which contain the patient's demographics, history, laboratory investigation reports and prescribed drugs. 


\section{Study criteria}

Patients were selected based on the following

\section{* Inclusion Criteria}

- Non-alcoholic individuals, between the age group of 20 60 years, irrespective of either sex.

- Patients with raised Liver Funtion test (LFT) and Fatty Liver Disease on Abdominal Ultrasonography (Patients with Grade 1 and Grade 2).

- Patients fit for Ruksha virechana.

* Exclusion Criteria

- History of alcohol abuse.

- Patients with uncontrolled DM/HTN

- Patients with Grade 3 Fatty Liver on Abdominal Ultrasonography.

- Patients with T.B., HIV, HBsAg, Obstructive jaundice, Viral hepatitis,Drug induced Hepatitis and other systemic disorders.

- Evidence of moderate to severe Ascites, Fibrosis, Cirrhosis, Splenomegaly, Jaundice, Hepatic Encephalopathy, etc.

\section{Diagnostic criteria}

Diagnosis was entirely based on subjective and objective findings of Non Alcoholic Steatohepatitis and Yakritodara.

\section{Parameters of the study}

Following subjective and objective criterias were considered for the study.

\section{Subjective Parameters}

- Loss of appetite

- Nausea

- Vomiting

- Abdominal pain/dull aching pain in the right Hypochondriac region.

- Yellowish discolouration of skin, urine and sclera (IF ANY).

\section{$>$ Objective Parameters}

- Fatty liver on USG gradings.

- Appropriate investigations were done if necessary.

\section{$>$ Assessment Criteria}

Overall assessment was done based on the improvement in Subjective and Objective Parameters before and after treatment which was subjected to Statistical Analysis.

Marked Relief

- Above $75 \%$ Improvement

Moderate Relief -50 to $75 \%$ Improvement

Mild Relief

No Relief
-25 to $50 \%$ Improvement

- Below 25\% Improvement

\section{Intervention}

A minimum of 20 subjects fulfilling the inclusion criteria were selected for the study in Group A and intervention was carried out. After a proper washout period of 15 days, the same 20 subjects were posted in Group B as the idea of study design was a clinical Cross over study.

\begin{tabular}{|c|c|}
\hline \multicolumn{2}{|c|}{ Aamapachana } \\
\hline \multicolumn{2}{|c|}{$\begin{array}{l}\text { Ajamodadi Churna - 3-5grams (twice a day) with Ushna } \\
\text { Jala before food till Nirama lakshanas were seen. }\end{array}$} \\
\hline \multicolumn{2}{|c|}{ Virechana (Ruksha Virechana) } \\
\hline \multicolumn{2}{|c|}{$\begin{array}{c}\text { Dashamoola Panchakoladi Kashaya } 30-45 \mathrm{ml} \text { (As per the } \\
\text { koshta and agni bala of the patient) }\end{array}$} \\
\hline \multicolumn{2}{|c|}{ Shamanoushadhi } \\
\hline \multirow[t]{2}{*}{$\begin{array}{l}\text { Lashuna Erandadi } \\
\text { Kashaya }\end{array}$} & $\begin{array}{cc}\text { Matra } & -15 \mathrm{ml} \text { (twice a } \\
\text { day) }\end{array}$ \\
\hline & $\begin{array}{cc}\text { Anupana } & - \text { Ushna Jala } \\
\text { Duration } & -45 \text { days }\end{array}$ \\
\hline \multicolumn{2}{|c|}{ Follow up during treatment: Once in 15 days. } \\
\hline \multicolumn{2}{|c|}{ Total duration of the study: 60 days. } \\
\hline
\end{tabular}

\begin{tabular}{|c|c|}
\hline \multicolumn{2}{|c|}{ Aamapachana } \\
\hline \multicolumn{2}{|c|}{$\begin{array}{l}\text { Ajamodadi Churna - 3-5grams (twice a day) with Ushna } \\
\text { Jala before food till Nirama lakshanas were seen. }\end{array}$} \\
\hline \multicolumn{2}{|c|}{ Virechana (Ruksha Virechana) } \\
\hline \multicolumn{2}{|c|}{$\begin{array}{l}\text { Dashamoola Panchakoladi Kashaya } 30-45 \mathrm{ml} \text { (As per the } \\
\text { koshta and agni bala of the patient) }\end{array}$} \\
\hline \multicolumn{2}{|c|}{ Shamanoushadhi } \\
\hline \multirow[t]{3}{*}{ Patolamooladi Kashaya } & $\begin{array}{l}\text { Matra }-15 \mathrm{ml} \\
\quad \text { (twice a day) }\end{array}$ \\
\hline & Anupana Jala - Ushna \\
\hline & $\underset{\text { days }}{\text { Duration }}-45$ \\
\hline \multicolumn{2}{|c|}{ Follow up during treatment: Once in 15 days. } \\
\hline \multicolumn{2}{|c|}{ Total duration of the study: 60 days. } \\
\hline
\end{tabular}

\section{RESULTS}

\begin{tabular}{|c|c|c|c|c|c|}
\hline $\begin{array}{c}\text { Subjects } \\
\text { screened }\end{array}$ & Withdrawal & Group & Included & $\begin{array}{c}\text { Drop } \\
\text { out }\end{array}$ & Completed \\
\hline \multirow{2}{*}{28} & \multirow{2}{*}{2} & $\mathrm{~A}$ & 26 & 03 & 23 \\
\cline { 3 - 6 } & & $\mathrm{B}$ & 23 & 02 & 21 \\
\hline
\end{tabular}

Table 3:- Study Chart

\section{Effect of Therapies}

26 subjects were registered in this clinical trial in Group A with 3 dropouts.So in Group A,23 subjects completed the first intervention.As per the Cross over study design, after a washout period of 15 days,the same 23 subjects were posted to the second intervention in Group B with 2 dropouts. So,in total 21 subjects completed the study. The cardinal symptoms were considered for statistical analysis and were assessed twice before and after the completion of treatment of 120 days. Along with the symptomatology, the fatty liver gradings on USG were also assessed by comparing the changes before and after treatment. 
ISSN No:-2456-2165

All the symptoms were scored on self-prepared scale and those scores were analyzed with statistical analyzing software.
Wilcoxon signed rank test was applied to interpret the observations within the group. Mann-Whitney U test was applied to compare the effectiveness in both groups.

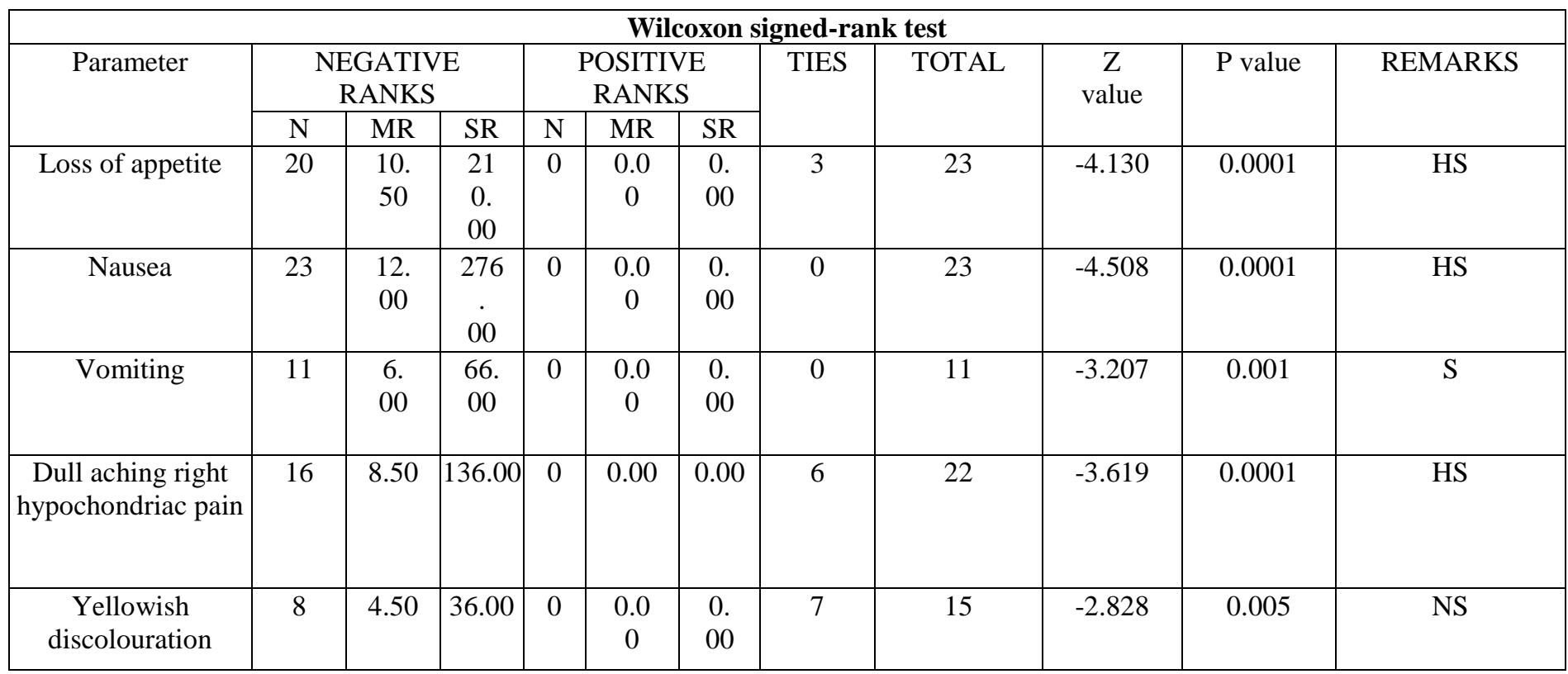

Table 4:- Effect of Therapy on Subjective Parameters of Group A

MR-Mean Rank, SR-Sum of Ranks, HS - Statistically Highly significant, S - Statistically significant,NS- Statistically Not Significant

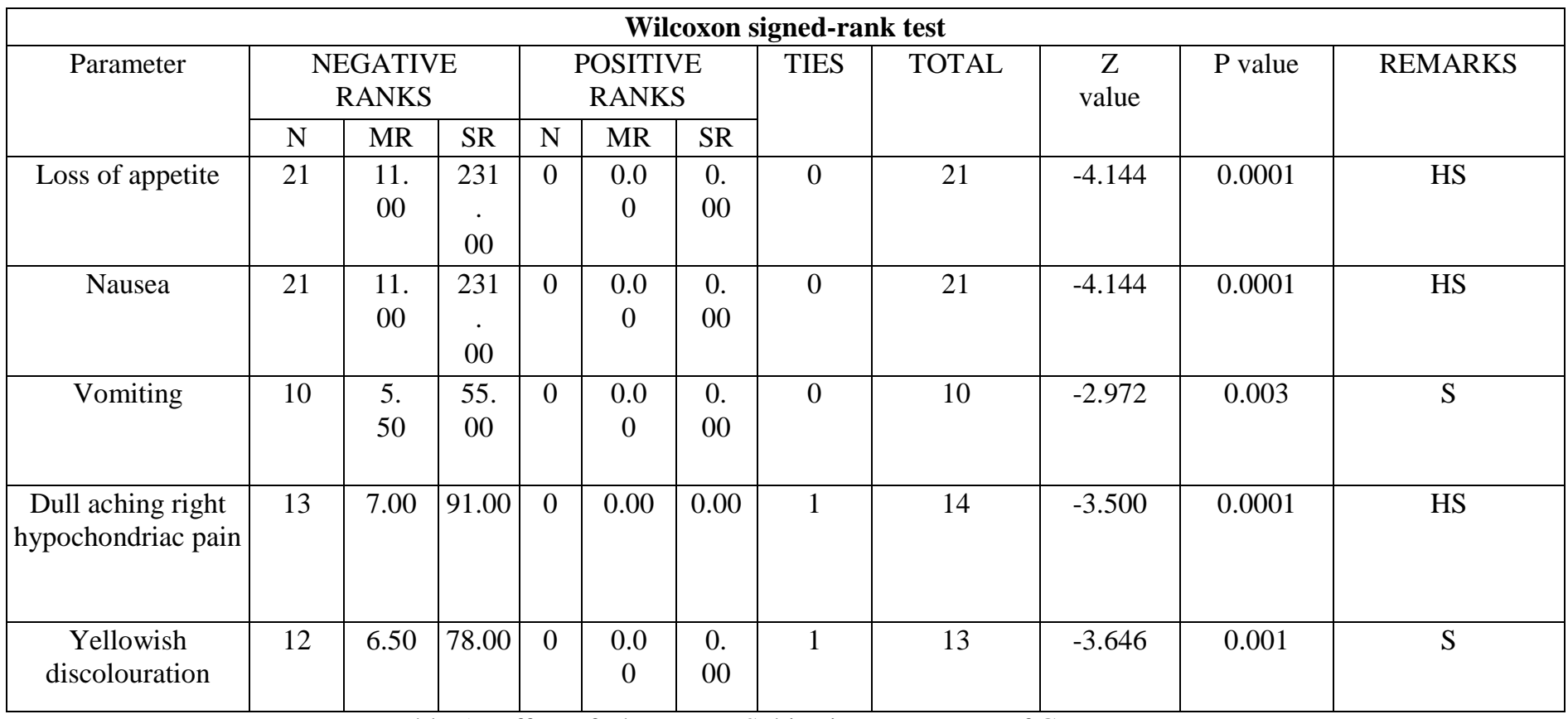

Table 5:- Effect of Therapy on Subjective Parameters of Group B

MR-Mean Rank, SR-Sum of Ranks, HS - Statistically Highly significant, S - Statistically significant 
ISSN No:-2456-2165

\begin{tabular}{|c|c|c|c|c|c|c|c|c|c|c|c|}
\hline \multicolumn{12}{|c|}{ Wilcoxon signed-rank test } \\
\hline \multirow{2}{*}{$\begin{array}{c}\text { USG } \\
\text { Grading of fatty } \\
\text { liver }\end{array}$} & \multicolumn{3}{|c|}{$\begin{array}{l}\text { NEGATIVE } \\
\text { RANKS }\end{array}$} & \multicolumn{3}{|c|}{$\begin{array}{l}\text { POSITIVE } \\
\text { RANKS }\end{array}$} & \multirow[t]{2}{*}{ TIES } & \multirow[t]{2}{*}{ TOTAL } & \multirow[t]{2}{*}{$\begin{array}{c}\mathrm{Z} \\
\text { value }\end{array}$} & \multirow[t]{2}{*}{$\mathrm{P}$ value } & \multirow[t]{2}{*}{ REMARKS } \\
\hline & $\mathrm{N}$ & MR & SR & $\mathrm{N}$ & MR & SR & & & & & \\
\hline Group A & 14 & $\begin{array}{l}7 . \\
50\end{array}$ & $\begin{array}{c}105 \\
.\end{array}$ & 0 & $\begin{array}{c}0.0 \\
0\end{array}$ & $\begin{array}{c}0 . \\
00\end{array}$ & 9 & 23 & -3.742 & 0.0001 & HS \\
\hline Group B & 21 & $\begin{array}{l}11 . \\
00\end{array}$ & $\begin{array}{c}231 \\
.\end{array}$ & 0 & $\begin{array}{c}0.0 \\
0\end{array}$ & $\begin{array}{l}0 . \\
00\end{array}$ & 0 & 21 & -4.583 & 0.0001 & HS \\
\hline
\end{tabular}

Table 6:- Effect of Therapy on Objective Parameter of Group A \& Group B

MR-Mean Rank, SR-Sum of Ranks, HS- Statistically Highly Significant

Comparison of Effect of Therapy on Subjective Parameter

\begin{tabular}{|c|c|c|c|c|c|c|c|}
\hline \multicolumn{8}{|c|}{ Mann Whitney U Test } \\
\hline Loss of appetite & $\mathrm{N}$ & MR & SR & $\begin{array}{l}\text { Mann Whitney } \\
\text { U Value }\end{array}$ & $\mathrm{Z}$ value & $\mathrm{P}$ value & REMARKS \\
\hline Group A & 23 & 32.83 & 755.00 & 4.000 & -6.019 & 0.0001 & HS \\
\hline Group B & 21 & 11.19 & 235.00 & & & & \\
\hline
\end{tabular}

Table 7:- Comparison of Effect of Therapy on Loss of Appetite

MR-Mean Rank, SR-Sum of Ranks, HS - Statistically Highly significant

\begin{tabular}{|c|c|c|c|c|c|c|c|}
\hline \multicolumn{8}{|c|}{ Mann Whitney U Test } \\
\hline Nausea & $\mathrm{N}$ & MR & SR & $\begin{array}{c}\text { Mann } \\
\text { Whitney U Value }\end{array}$ & $\mathrm{Z}$ value & $\mathrm{P}$ value & REMARKS \\
\hline Group A & 23 & 29.80 & 685.50 & 73.500 & -4.571 & 0.0001 & HS \\
\hline Group B & 21 & 14.50 & 304.50 & & & & \\
\hline
\end{tabular}

Table 8:- Comparison of Effect of Therapy on Nausea

MR-Mean Rank, SR-Sum of Ranks, HS - Statistically Highly significant

\begin{tabular}{|c|c|c|c|c|c|c|c|}
\hline \multicolumn{9}{|c|}{} & $\mathrm{N}$ & MR & SR & $\begin{array}{c}\text { Mann } \\
\text { Whitney U Value }\end{array}$ & Z value & P value & REMARKS \\
\hline Vomiting & 12 & 12.57 & 153.00 & 45.000 & -1.662 & 0.096 & NS \\
\hline Group A & 10 & 10.00 & 100.00 & & \\
\hline
\end{tabular}

Table 9:- Comparison of Effect of Therapy on Vomiting

MR-Mean Rank, SR-Sum of Ranks, NS- Statistically Not Significant.

\begin{tabular}{|c|c|c|c|c|c|c|c|}
\hline \multicolumn{8}{|c|}{ Mann Whitney U Test } \\
\hline $\begin{array}{c}\text { Dull aching right } \\
\text { hypochondriac pain }\end{array}$ & $\mathrm{N}$ & MR & SR & $\begin{array}{l}\text { Mann Whitney } \\
\text { U Value }\end{array}$ & $\mathrm{Z}$ value & $\mathrm{P}$ value & REMARKS \\
\hline Group A & 22 & 21.77 & 479.00 & 82.000 & -2.532 & 0.011 & $S$ \\
\hline Group B & 14 & 13.36 & 187.00 & & & & \\
\hline
\end{tabular}

Table 10:- Comparison of Effect of Therapy on Dull Aching Pain

MR-Mean Rank, SR-Sum of Ranks, S - Statistically significant 
ISSN No:-2456-2165

\begin{tabular}{|c|c|c|c|c|c|c|c|}
\hline \multicolumn{9}{|c|}{ Mann Whitney U Test } \\
\hline $\begin{array}{c}\text { Yellowish } \\
\text { discolouration }\end{array}$ & $\mathrm{N}$ & MR & SR & $\begin{array}{c}\text { Mann } \\
\text { Whitney U Value }\end{array}$ & Z value & P value & REMARKS \\
\hline Group A & 15 & 17.03 & 255.50 & 59.500 & -2.236 & 0.025 & S \\
\hline Group B & 13 & 11.58 & 150.50 & & & \\
\hline
\end{tabular}

Table 11:- Comparison of Effect of Therapy on Yellowish Discolouration

MR-Mean Rank, SR-Sum of Ranks, S - Statistically significant

\begin{tabular}{|c|c|c|c|c|c|c|c|}
\hline \multicolumn{9}{|c|}{ Mann Whitney U Test } \\
$\begin{array}{c}\text { USG Gradings of fatty } \\
\text { liver }\end{array}$ & $\mathrm{N}$ & MR & SR & $\begin{array}{c}\text { Mann } \\
\text { Whitney U Value }\end{array}$ & Z value & P value & REMARKS \\
\hline Group A & 23 & 30.61 & 704.00 & 55.000 & -4.737 & 0.0001 & HS \\
\hline Group B & 21 & 13.62 & 286.00 & & & \\
\hline
\end{tabular}

Table 12:- Comparison of Effect of Therapy on Objective Parameter

MR-Mean Rank, SR-Sum of Ranks, HS - Statistically Highly significant

\begin{tabular}{|c|c|c|c|}
\hline \multirow[t]{2}{*}{ Parameter } & \multicolumn{2}{|c|}{ Mean } & \multirow[t]{2}{*}{ Percentage of Relief } \\
\hline & BT & AT & \\
\hline Loss of appetite & 2.0 & 0.3 & $85 \%$ \\
\hline Nausea & 1.70 & 0.20 & $88.23 \%$ \\
\hline Vomiting & 2.3 & 0.2 & $91.30 \%$ \\
\hline Dull aching right hypochondriac pain & 1.68 & 0.34 & $79.76 \%$ \\
\hline $\begin{array}{l}\text { Yellowish discolouration of skin, urine and } \\
\text { sclera }\end{array}$ & 0.933 & 0.06 & $93.56 \%$ \\
\hline USG gradings of fatty liver & 1.66 & 0.366 & $77.99 \%$ \\
\hline
\end{tabular}

Table 13:- Effect of Therapy on Subjective and Objective Parameters of the Study

\begin{tabular}{|c|c|c|}
\hline Sl. NO & Percentage of Relief & Remarks \\
\hline 1 & $60 \%$ & Moderate relief \\
\hline 2 & $84.61 \%$ & Marked Relief \\
\hline 3 & $78.50 \%$ & Marked Relief \\
\hline 4 & $72.22 \%$ & Moderate relief \\
\hline 5 & $63.63 \%$ & Moderate relief \\
\hline 6 & $100 \%$ & Marked Relief \\
\hline 7 & $94.11 \%$ & Marked Relief \\
\hline 8 & 89.47 & Marked Relief \\
\hline 9 & $90 \%$ & Marked Relief \\
\hline 10 & $100 \%$ & Marked Relief \\
\hline 11 & $100 \%$ & Marked Relief \\
\hline 12 & $81.25 \%$ & Marked Relief \\
\hline 13 & $90.90 \%$ & Marked Relief \\
\hline 14 & $100 \%$ & Marked Relief \\
\hline 15 & $100 \%$ & Marked Relief \\
\hline 16 & $82.14 \%$ & Marked Relief \\
\hline 17 & $60 \%$ & Moderate relief \\
\hline 18 & $72.72 \%$ & Moderate relief \\
\hline 19 & $91.53 \%$ & Marked Relief \\
\hline 20 & $26.19 \%$ & Mild relief \\
\hline 21 & $100 \%$ & Marked Relief \\
\hline
\end{tabular}

Table 14:- Showing Effect of Therapy on Individual Subjects 


\begin{tabular}{|c|c|c|c|}
\hline Relief & No. of subjects & Percentage & Remarks \\
\hline Above $75 \%$ & 15 & $71.42 \%$ & Marked relief \\
\hline $51 \%$ to $75 \%$ & 5 & $23.80 \%$ & Moderate relief \\
\hline $26 \%$ to $50 \%$ & 1 & $4.76 \%$ & Mild relief \\
\hline Less than $25 \%$ & 0 & 0 & No relief \\
\hline
\end{tabular}

Table 15:- Distribution of Subjects According to Overall Assessment of the Result

\section{DISCUSSION}

In this study, "Ajamodadi churna" was selected for Amapachana which has deepana, pachana, vata kaphahara effect and along with it, possesses vatanulomaka property. Virechana is the most suitable Shodhana Karma for Pittaja and Raktaja Vikara.Yakrit is the Moolasthana of Raktavaha

Srotas and hence,Virechana is the sreshta chikitsa. Ruksha Virechana was adopted in the present study on NASH as it is a Santarpana janya vyadhi. If Snigdha Virechana is given, then doshas will get adhered in the other Srotas instead of being expelled out.

Ruksha virechana was administered with Dashamoola Panchakoladi Kashaya main ingredients are Trivrit and Danti.Trivrit is one among the bhedaniya mahakashaya,tridosha hara and has rechaka property.Danti acts as deepana, pachana, sramsani, srusthavinmutra, rechaka, adhobhagahara and bhedana.

The shamanoushadhi i.e. Lashuna Erandadi and Patolamooladi kashaya acts as Amapachaka, Agni Dipaka,Vatakaphahara,Mridurechaka,Shophahara and Shulahara that helps in disintegrating the pathogenesis of NASH.The shamanoushadhi's are dominant in Tikta rasa which has Raktashodhaka and Raktaprasadaka properties.Because of its Yakrit Uttejaka karma and Pitta saraka properties, it stimulates liver, reduces the engorgement in liver. Thus, the congestion in liver and parenchyma is subsided.This is essential for samprapti vighatana of kaphaja yakrit roga.Hence, the above mentioned formulations have pitta rechaka, raktashodhaka, yakrituttejaka properties.

The liver damage becomes irreversible as it progresses to Fibrosis and Cirrhosis, hence steps should be taken to treat the disease at the initial stages and to stop it from progressing to irreversible condition. Hence, it is the need of the hour to search an effective and safe Hepatoprotective ideal remedy from Ayurvedic treasure of therapeutics for the welfare of mankind.

\section{CONCLUSION}

$\mathrm{NASH}$, a lifestyle disorder, is emerging as the second leading cause for Liver Transplantation worldwide. There is no direct reference of NASH in Ayurvedic classics. The etiopathogenesis of NASH and Yakritodara simulate.Hence, we can correlate it with Yakritodara.NASH is a Santarpanajanya vyadhi.The cross over study design proved that along with the relief of symptoms, there was significant reduction in the grades of fatty liver on USG among the subjects of NASH. Overall study showed marked improvement in $60 \%$ of cases and Moderate improvement in $26.66 \%$. Hence, it can be concluded that the combined effect of therapy with Amapachana,Ruksha virechana and Shamanoushadhi's (Lashuna Erandadi Kashaya and Patolamooladi Kashaya) has shown a significant role in relieving the signs and symptoms of subjects diagnosed with Non Alcoholic Steatohepatitis.

\section{REFERENCES}

[1]. http://medind.nic.in/ica (accessed 30 December 2010).Ajay Duseja.Non Alcoholic fatty liver disease in India.

[2]. Loscalzo J, Fauci A S, Braunwald E, Hauser S L, Kasper D L, Longo D L,Harisson's Principles of Internal Medicine, $17^{\text {th }}$ Edition, Vol 2,Part 13,Section 2,Chapter 302,Page No. 1973.

[3]. Harsh Mohan, Harsh Mohan Text Book Of Pathology, $6^{\text {th }}$ edition 2010,Chapter 21, The Liver,Biliary Tract and exocrine Pancreas,Jaypee brothers medical publishers, New Delhi, Page No. 629.

[4]. https://www.ncbi.nlm.nih.gov/pubmed/24772746.http s://www.ncbi.nlm.nih.gov/pubmed/24772746. Study of prevalance of Nonalcoholic Fatty Liver Disease(NAFLD) in Type 2 Diabetic patients in India ,KalraS,etal.JAssoc Physicians India.2013 /jul;61(7):448-53.

[5]. Bhavamishra, Bhavaprakasha with Vidyotini Hindi Commentary,Purvakhanda, ${ }^{\text {th }}$ Edition 1999,Chaukhamba Sanskrit Samsthana Varanasi, Chapter 3,Verse 317,Page No.60. 
[6]. Acharya Vidyadhar Shukla,Prof. Ravi DuttTripathi,Charaka Samhita of Agnivesha, VaidyaManorama Hindi Commentary, Chaukambha Sanskrit Pratishthan,Delhi,Vol 1, Vimanasthana, $5^{\text {th }}$ Chapter,Page No. 588.

[7]. Bhavamishra, Bhavaprakasha with Vidyotini Hindi Commentary,Madhyama Khanda, $3^{\text {rd }}$ Edition, Chaukhamba Sanskrit Series Office, Varanasi, Chapter 41, Verse 17-18,Page No.417-418.

[8]. https://www.ncbi.nlm.nih.gov/pmc/articles/PMC2683 460/- Non alcoholic fatty liver disease two-hit process: multifactorial character of the second hit.

[9]. https://www.ncbi.nlm.nih.gov/pmc/articles/PMC6863 115/ Ganguli S, DeLeeuw P, Satapathy SK. A Review Of Current And Upcoming Treatment Modalities In Non-Alcoholic Fatty Liver Disease And NonAlcoholic Steatohepatitis. Hepat Med. 2019;11:159178. Published 2019 Nov 15. doi:10.2147/ HMER.S188991.

[10]. Dr. Brahmanand Tripathi, Sharangdhara Samhita,Dipika Hindi Commentary,Madhyama Khanda,Chaukambha Surbharti Prakashan, Varanasi, $6^{\text {th }}$ Chapter,Verse 53,Page No.121.

[11]. Dr.K.Nishteshwar,Dr.R.Vidyanath,Sahasrayoga,Engli sh Translation,Reprint 2017, Chowkhamba Sanskrit Series Office, Varanasi, Kashaya Prakarna,Serial No.45, Page No.35.

[12]. Dr.K.Nishteshwar,Dr.R.Vidyanath,Sahasrayoga,Engli sh Translation,Reprint 2017, Chowkhamba Sanskrit Series Office, Varanasi, Kashaya Prakarna,Serial No.42,Page No.32.

[13]. Kaviraj Atridev Gupta, Ashtanga Hridayam,Vidyotini Hindi Commentary, Edition: Reprinted 2017,Chaukhambha Prakashan,Varanasi, Chapter 19, Kushta Chikitsa Adhyaya,Verse 28-30,Page No.555. 